\title{
Commentary \\ ICU staffing and patient outcomes: more work remains
}

\section{David J Murphy, Eddy Fan and Dale M Needham}

Pulmonary and Critical Care Medicine, Johns Hopkins Medical Institutions, 1830 E. Monument Street, Baltimore, MD 21205, USA

Corresponding author: Dale M Needham, dale.needham@jhmi.edu

Published: 7 January 2009

Critical Care 2009, 13:101 (doi:10.1186/cc7113)

This article is online at http://ccforum.com/content/13/1/101

(C) 2009 BioMed Central Ltd

See related research by Cooke et al., http://ccforum.com/content/12/6/R134

\begin{abstract}
Many studies have demonstrated that closed intensive care units (ICUs), staffed by trained intensivists, are associated with improved patient outcomes. However, the mechanisms by which ICU organizational factors, such as physician staffing, influence patient outcomes are unclear. One potential mechanism is the increased utilization of evidence-based practices in closed ICUs. Cooke and colleagues investigated this hypothesis in a cohort of 759 acute lung injury patients in 23 ICUs in King County, Washington, USA. Although closed ICUs were independently associated with a modestly lower mean tidal volume, this finding did not explain the mortality benefit associated with a closed ICU model in this patient cohort. Future studies should evaluate other potential mechanisms by which closed ICUs improve patient outcomes. An improved understanding of these mechanisms may yield new targets for improving the quality of medical care for all ICU patients.
\end{abstract}

The mechanisms by which closed intensive care units (ICUs), defined as units in which patient care is directed by board certified intensivists, improve patient outcomes are unclear. Increased use of low tidal volume ventilation (LTVV) has been hypothesized as a mechanism underlying the lower hospital mortality observed in acute lung injury (ALI) patients treated in closed ICUs. To investigate this issue, Cooke and colleagues [1] assessed the effect of a closed ICU physician staffing model on the provision of LTVV for ALI patients. In their secondary analysis of data from an observational cohort of $759 \mathrm{ALI}$ patients from 10 open and 13 closed ICUs, Cooke and colleagues examined differences in tidal volume 3 days after ALI onset. Patients in closed versus open ICUs received modestly lower mean tidal volumes (9.3 versus $10.8 \mathrm{~mL} / \mathrm{kg}$ predicted body weight, $p<0.001)$. However, adjusting for this difference in tidal volume did not influence the odds ratio for hospital mortality in closed versus open ICUs (crude and adjusted odds ratios: 0.73 and 0.74 , respectively).

In this study, the mean weekday coverage by intensivists was similar between open and closed ICUs (6.8 versus 7.3 hours, $p=0.84)$. Consequently, ALI patients in both closed and open ICUs in the King County cohort may have received relatively similar 'doses' of intensivist care. In particular, there was a lack of difference in ALI quality indicators measured in this study. For example, open and closed ICUs were similar with respect to: documentation of ALI/pulmonary edema (46\% and $47 \%$, respectively); measurement of patient height as required for calculation of predicted body weight $(81 \%$ and $80 \%$, respectively); and the level of positive endexpiratory pressure (PEEP) provided on day 3 (median = $5 \mathrm{mmHg}$ in both open and closed ICUs).

The lower hospital mortality in closed versus open ICUs, which was previously reported in this patient cohort [2], may be explained by mechanisms not evaluated in this study. For instance, the closed ICUs may have had more timely patient evaluation and treatment initiation, which are important predictors of mortality in critically ill patients [3-5]. Alternatively, there may have been differences in ICU nurse staffing ratios or experience level, which can affect patient outcomes $[6,7]$. This issue of nurse experience may be particularly relevant to $A L I$ since ICU nurses with greater work experience have demonstrated increased knowledge regarding LTVV and reported lower barriers to providing it [8]. Furthermore, a closed ICU staffing model may more readily foster an interdisciplinary team-based approach to critical care with enhanced coordination, communication, and collaboration, which have been associated with improved patient outcomes [9]. Finally, closed ICUs may more frequently create and use clinical protocols, reminders, and checklists, which can improve the reliable provision of other aspects of evidencebased critical care [10-13].

Future studies should continue to evaluate potential mechanisms by which closed ICUs improve patient outcomes. Given the significant shortage of intensivists in some jurisdictions [14,15], understanding these mechanisms are

$\mathrm{ALI}=$ acute lung injury; $\mathrm{ICU}=$ intensive care $u$ nit $\mathrm{LTVV}=$ low tidal volume ventilation; $\mathrm{PEEP}=$ positive end-expiratory pressure. 
particularly important for improving the quality of medical care for patients in all types of ICUs.

\section{Competing interests}

The authors declare that they have no competing interests.

\section{Acknowledgements}

DJM is supported by an institutional training grant from the National Institutes of Health (T32 HL007534). EF is supported by a Fellowship Award from the Canadian Institutes of Health Research. DMN is supported by a Clinician-Scientist Award from the Canadian Institutes of Health Research.

\section{References}

1. Cooke CR, Watkins TR, Kahn JM, Treggiari MM, Caldwell E, Hudson L, Rubenfeld GD: The effect of intensive care unit staffing model on tidal volume in patients with acute lung injury. Crit Care 2008, 12:R134.

2. Treggiari MM, Martin DP, Yanez ND, Caldwell E, Hudson LD, Rubenfeld GD: Effect of intensive care unit organizational model and structure on outcomes in patients with acute lung injury. Am J Respir Crit Care Med 2007, 176:685-690.

3. Kumar A, Roberts D, Wood KE, Light B, Parrillo JE, Sharma S, Suppes R, Feinstein D, Zanotti S, Taiberg L, Gurka D, Kumar A, Cheang M: Duration of hypotension before initiation of effective antimicrobial therapy is the critical determinant of survival in human septic shock. Crit Care Med 2006, 34:1589-1596.

4. McNamara RL, Wang Y, Herrin J, Curtis JP, Bradley EH, Magid DJ, Peterson ED, Blaney M, Frederick PD, Krumholz HM: Effect of door-to-balloon time on mortality in patients with ST-segment elevation myocardial infarction. J Am Coll Cardiol 2006, 47: 2180-2186

5. Jones AE, Brown MD, Trzeciak S, Shapiro NI, Garrett JS, Heffner $A C$, Kline JA: The effect of a quantitative resuscitation strategy on mortality in patients with sepsis: a meta-analysis. Crit Care Med 2008, 36:2734-2739.

6. Pronovost PJ, Jenckes MW, Dorman T, Garrett E, Breslow MJ, Rosenfeld BA, Lipsett PA, Bass E: Organizational characteristics of intensive care units related to outcomes of abdominal aortic surgery. JAMA 1999, 281:1310-1317.

7. Morrison AL, Beckmann U, Durie M, Carless R, Gillies DM: The effects of nursing staff inexperience (NSI) on the occurrence of adverse patient experiences in ICUs. Aust Crit Care 2001, 14:116-121.

8. Dennison CR, Mendez-Tellez PA, Wang W, Pronovost PJ, Needham DM: Barriers to low tidal volume ventilation in acute respiratory distress syndrome: survey development, validation, and results. Crit Care Med 2007, 35:2747-2754.

9. Baggs JG, Schmitt MH, Mushlin Al, Mitchell PH, Eldredge DH, Oakes $\mathrm{D}$, Hutson AD: Association between nurse-physician collaboration and patient outcomes in three intensive care units. Crit Care Med 1999, 27:1991-1998.

10. Umoh NJ, Fan E, Mendez-Tellez PA, Sevransky JE, Dennison CR, Shanholtz C, Pronovost PJ, Needham DM: Patient and intensive care unit organizational factors associated with low tidal volume ventilation in acute lung injury. Crit Care Med 2008, 36:1463-1468

11. Rana R, Afessa B, Keegan MT, Whalen FX Jr, Nuttall GA, Evenson LK, Peters SG, Winters JL, Hubmayr RD, Moore SB, Gajic O; Transfusion in the ICU Interest Group: Evidence-based red cell transfusion in the critically ill: quality improvement using computerized physician order entry. Crit Care Med 2006, 34:18921897.

12. Berenholtz SM, Pronovost PJ, Lipsett PA, Hobson D, Earsing K, Farley JE, Milanovich S, Garrett-Mayer E, Winters BD, Rubin HR, Dorman T, Perl TM: Eliminating catheter-related bloodstream infections in the intensive care unit. Crit Care Med 2004, 32: 2014-2020.

13. Brook AD, Ahrens TS, Schaiff R, Prentice D, Sherman G, Shannon W, Kollef MH: Effect of a nursing-implemented sedation protocol on the duration of mechanical ventilation. Crit Care Med 1999, 27:2609-2615.
14. Angus DC, Shorr AF, White A, Dremsizov TT, Schmitz RJ, Kelley MA: Critical care delivery in the United States: distribution of services and compliance with Leapfrog recommendations. Crit Care Med 2006, 34:1016-1024.

15. Kelley MA, Angus D, Chalfin DB, Crandall ED, Ingbar D, Johanson W, Medina J, Sessler CN, Vender JS: The critical care crisis in the United States: a report from the profession. Chest 2004, 125:1514-1517. 